\title{
Ramosetron for the prevention of postoperative nausea and vomiting (PONV): a meta-analysis
}

\author{
Won Oak Kim, Bon Nyeo Koo, Yong Kook Kim, and Hae Keum Kil \\ Department of Anesthesiology and Pain Medicine, Anesthesia and Pain Research Institute, Yonsei University College of Medicine, \\ Seoul, Korea
}

Background: Postoperative nausea and vomiting (PONV) remains a challenge for patients and health professionals despite various newly developed prophylactic interventions. We reviewed the efficacy and safety of ramosetron in randomized controlled trials (RCTs) for the prevention of PONV.

Methods: We reviewed 18 randomized controlled trials investigating the efficacy and safety of ramosetron in comparison with placebo or any other drugs. Relevant studies were searched in the MEDLINE, SCOPUS, and the Cochrane database libraries. Our end points of concern were prevention of PONV and adverse effects as dichotomous data.

Results: The prophylactic effect of $0.3 \mathrm{mg}$ ramosetron was observed in early PON (relative risk, RR: 0.4; 95\% CI 0.30.6), early POV (RR: $0.3 ; 95 \%$ CI $0.1-0.6$ ), late POV (RR: 0.3 ; 95\% CI $0.1-0.6$ ), but not late PON (RR: 0.7; 95\% CI 0.51.0). Compared with placebo, the efficacy of $0.3 \mathrm{mg}$ ramosetron in adults and $6 \mu \mathrm{g} / \mathrm{kg}$ in children were consistently beneficial in preventing PONV overall (RR: 0.4; 95\% CI: 03-0.6). The effects of $0.3 \mathrm{mg}$ ramosetron and $3 \mathrm{mg}$ granisetron were similar. No serious side effects or adverse events resulted from ramosetron and other active drugs, and incidence was similar to those of the placebo group.

Conclusions: Ramosetron is effective and safe in children and adults without serious adverse effects compared with placebo or other active drugs, as shown in pooled data of RCTs, in terms of the prevention of PONV. (Korean J Anesthesiol 2011; 61: 405-412)

Key Words: Antiemetics, Meta-analysis, PONV, Ramosetron.

Received: March 18, 2011. Accepted: May 11, 2011.

Corresponding author: Won Oak Kim, M.D., Department of Anesthesiology and Pain Medicine, Anesthesia and Pain Research Institute, Yonsei University College of Medicine, CPO box 8044, Seoul 120-752, Korea. Tel: 82-2-2228-2413, Fax: 82-2-312-7185, E-mail: wokim@yuhs.ac (c) This is an open-access article distributed under the terms of the Creative Commons Attribution Non-Commercial License (http:// creativecommons.org/licenses/by-nc/3.0/), which permits unrestricted non-commercial use, distribution, and reproduction in any medium, provided the original work is properly cited. 


\section{Introduction}

Postoperative nausea and vomiting (PONV) is one of the most common complaints following anesthesia and serious complications of clinical concern in the postoperative period [1,2]. It is often associated with increased morbidity of postoperative bleeding, wound dehiscence, pulmonary aspiration of gastric contents, fluid and electrolyte imbalance, dehydration, delayed hospital discharge, unexpected hospital admission, and decreased satisfaction in surgical patients [3]. PONV without prophylaxis is a serious and common cause of significant problems, especially in children $[4,5]$. Reported incidence of overall PONV is between 20 and $30 \%$ but can increase up to $80 \%$ in high-risk patients. PONV seems to be considered multi-factorial, involving anesthetic, surgical, and individual risk factors [6]. Pharmacological and nonpharmacological methods are currently available to prevent PNOV.

Several antiemetics are used for the prevention or relief of PONV [7-9]. Consequently, even children better tolerated PONV with antiemetics, as these drugs lessened the risk and distress associated with it $[4,5,10]$. PONV and discomfort needs to be properly controlled to relieve patients' suffering and achieve better outcomes.

Among antiemetics, ramosetron, a selective serotonin 5-hydroxytryptamine type $3\left(5-\mathrm{HT}_{3}\right)$ receptor antagonist, has better inhibitory activities than those of formerly available antagonists such as ondansetron, granisetron, and tropisetron. Ramosetron is more potent and has longer-lasting antiemetic effects than older agents because of a slower rate of dissociation from the target receptor and higher binding affinity [11]. This class of selective $5-\mathrm{HT}_{3}$ receptor antagonists prevents serotonin binding to $5-\mathrm{HT}_{3}$ receptors at the ends of the vagal afferent branches, which directly signals the vomiting center in the medulla oblongata and in the chemoreceptor trigger zone of the brain $[11,12]$.

The object of this quantitative systemic review was to define the evidence in published randomized controlled trials (RCTs) concerning the efficacy and safety of ramosetron in preventing PONV. We extensively reviewed the literature and evaluated the pharmacologic efficacy and safety of ramosetron in the prevention of PONV.

\section{Materials and Methods}

This study was undertaken following the guidance of the preferred reporting items for systemic reviews and metaanalysis (PRISMA) statement for performing quantitative systemic reviews $[13,14]$.

\section{Systematic search and strategy}

A systemic search of the relevant literature was performed without language limitation but restricted to RCTs available in English. We mainly explored MEDLINE using PUBMED and SCOPUS, the Cochrane database library using references found in reviews, or initially identified articles which were also used for further articles related to the topic. Published articles contained key words such as "ramosetron," "PONV," "nausea," "vomiting," "postoperative," "postoperative nausea and vomiting," and "antiemetics" in their titles or abstracts, and electronic searches were conducted until November 2010. The search strategy consisted of a combination of free text words as follows: "postoperative OR postanaesthetic OR postanesthetic OR surgical" AND "nausea OR emesis OR vomiting OR retching" AND "ramosetron OR nausea”. A copy of each paper was retrieved for final assessment of eligibility.

\section{Inclusion and exclusion criteria}

Inclusion criteria were as follows: (1) the study was published as a full report of randomized controlled trials that tested the efficacy and safety of ramosetron compared with placebo or any other drugs as control in the prophylaxis of PONV following general anesthesia; (2) the placebo was identical in appearance and had no active drugs; and (3) the subjects were human (adults and children), and all participants irrespective of sex, age, surgery, or age were considered. We did not include data from abstracts, posters, case reports, comments or letters to the editor, reviews, and animal studies. No attempts were made to obtain unpublished studies, nor did we request unpublished data from the company developing the drug.

\section{Definition of relevant outcome data}

Nausea was defined as subjectively having unpleasant feeling associated with being sick or awareness of the urge to vomit. Vomiting was defined as a forceful expulsion of gastric contents or retching that was defined as labored spasmodic, rhythmic contraction of the respiratory muscles without expulsion of gastric contents. PONV included both nausea and vomiting [15].

Many studies revealed evidence for different underlying PONV risk factors in children and the need for higher doses of prophylactic antiemetics in children, necessitating different preoperative risk scores than those used for adults [16]. Therefore, we separated the relevant outcome data for children and adults and analyzed accordingly. 


\section{Data extraction and quality assessment}

We retrieved patient information, including the type of surgery, drug dose, and route of administration, comparators, study end-points, adverse effects, and rescue medication. The outcome data of PONV at three time points were extracted: early period $(0-6 \mathrm{~h})$, late period $(\geq 6 \mathrm{~h})$, and the overall period $(0-24 / 48 \mathrm{~h})$. Antiemetic effects of early and late periods were only analyzed for $0.3 \mathrm{mg}$ ramosetron compared data because of inconsistencies or absences in reporting. When PONV events were presented at different times, we selected cumulative values near postoperative 6 hours and 24/48 hours. PONV events, including retching, were the primary outcomes, and incidence of adverse effects and the use of rescue medication were secondary outcomes. The primary and secondary outcomes were separately compiled. A single investigator examined and scored the retrieved reports using the five-point Oxford scale for validity assessment (randomization $0-2$, blinding $0-2$, description of withdrawals and dropouts $0-1$ ) [17].

\section{Quantitative analysis}

Collected data were recorded on formalized sheets, and values originally provided as percentages were converted into actual corresponding numbers (of patients and incidence) for analysis where needed. We computed the relative risk (RR) with corresponding 95\% confidence intervals (CIs) for dichotomous outcome data using a fixed-model, if no heterogeneity was present. Otherwise, a random-effects model was applied. Heterogeneity was judged with the $\mathrm{I}^{2}$-test, assuming heterogeneity if an $\mathrm{I}^{2}$ value of more than $25 \%$ was observed. When the $95 \%$ CI did not include the value 1.0, we assumed a statistically significant difference between an intervention and control. Subgroup analysis of the following items was performed to investigate relevant clinical heterogeneity: different doses, time of application, route of administration, and active-controlled versus placebo-controlled trials. We calculated the number needed to treat or to harm (NNT) as a useful estimate measure of the clinically significant effect. NNT is the number of patients that must be treated with an experimental intervention to achieve a particular result (beneficial or harmful) in one of them which would not have been the case had they all received the control intervention (placebo). A potential publication bias was explored with asymmetry of overall period PONV data using a funnel plot. Statistical analysis was performed using MIX 2.0 for Windows that was developed and validated by Leon Bax of the Department of Medical Informatics of Kitasato University in Japan $[18,19]$. Incidences of PONV with various doses of ramosetron were compared using Fisher's exact test using SPSS 13.0 for Windows, and $\mathrm{P}<0.05$ was considered significant.

\section{Results}

We identified 34 potential articles of randomized controlled trials through key words and free text words (Fig. 1). Eventually a total of 1888 subjects in 18 studies were included in the present systemic review. Sixteen pertinent studies were excluded. One of them had no accessible dichotomous data on PONV, and 4 trials were not available or inappropriate for use in this review (Table 1, studies 2, 3, 7, 22) [8]. Eleven articles were reviews, comments, or studies with inappropriate settings. The details of the trials are presented in Table 1.

The median quality of score was 3 (range: $2-5$ ). Nineteen trials were in adults, and three were in children (range: $4-10$ years). Some trials compared different doses of the same drug, and different regimens were evaluated such as oral and IV administrations, fixed doses (full milligram), and variable doses (microgram per kilogram body weight). Ramosetron was given at the end of surgery in 17 trials, while it was administered 30 minutes before the end of surgery in 1 trial. It was given before induction in four trials and after induction in 1 trial.

\section{Ramosetron dose (studies 8, 10, 12, 14)}

The incidence of overall PONV events (0-24/48 hours after anesthesia) was $56 \pm 15$ (\%, mean \pm SD) with placebo, $49 \pm$ 16 with $0.15 \mathrm{mg}$ ramosetron, $16 \pm 7$ with $0.3 \mathrm{mg}$ ramosetron, and $12 \pm 5$ with $0.6 \mathrm{mg}$ ramosetron. There was no significant difference between placebo and $0.15 \mathrm{mg}$ ramosetron or between $0.3 \mathrm{mg}$ and $0.6 \mathrm{mg}$ ramosetron. The most frequently used regimen of ramosetron was $0.3 \mathrm{mg}$ IV as a minimum effective dose; increasing the dose to $0.6 \mathrm{mg}$ provided no further benefit. In children, $6 \mu \mathrm{g} / \mathrm{kg}$ IV was the most effective dose (Table 1) [5,20-26].

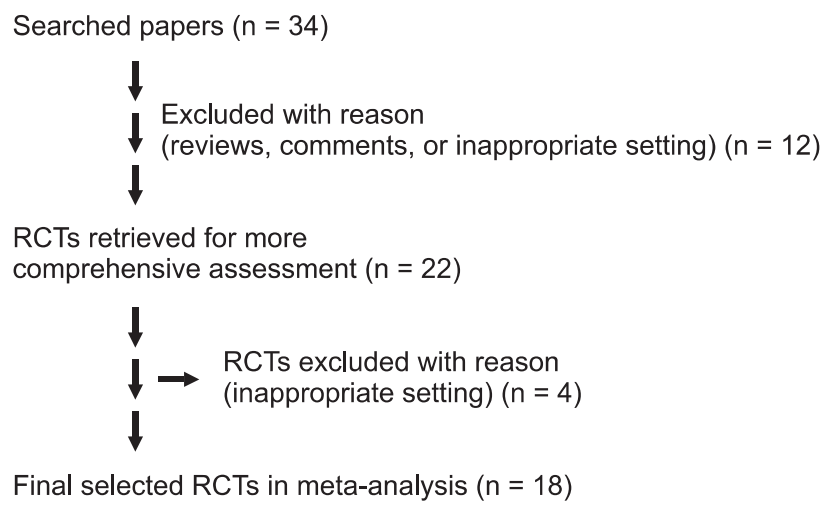

I $\rightarrow$ RCTs excluded with reason

Final selected RCTs in meta-analysis $(n=18)$

Fig. 1. Flow chart of article selection according to the guideline of PRISMA statement. RCTs: randomized, controlled, trials. 
Table 1. Summary of Randomized, Blinded, Controlled Trials

\begin{tabular}{|c|c|c|c|c|c|c|c|c|c|c|c|c|}
\hline Study ID & $\begin{array}{l}\text { Intervention/ } \\
\text { Control }\end{array}$ & $\mathrm{n}$ & $\begin{array}{l}\text { PON } \\
\text { (early) }\end{array}$ & $\begin{array}{l}\text { POV } \\
\text { (early) }\end{array}$ & $\begin{array}{l}\text { PON } \\
\text { (late) }\end{array}$ & $\begin{array}{l}\text { POV } \\
\text { (late) }\end{array}$ & $\begin{array}{c}\text { PONV } \\
\text { (overall) }\end{array}$ & $\begin{array}{l}\text { Rescue- } \\
\text { need }\end{array}$ & $\mathrm{AE}$ & Surgery & Time & Remarks \\
\hline Choi et al. [29] & $\mathrm{P}$ & 70 & & & & & 49 & 37 & & Cardiac surgery & E & \\
\hline \multirow[t]{3}{*}{ Study 1} & $\mathrm{O} 4+12$ (PCA) & 71 & & & & & 33 & 24 & & & & \\
\hline & R0.3 & 70 & & & & & 38 & 30 & & & & \\
\hline & R0.3 + 0.6 (PCA) & 68 & & & & & 24 & 20 & & & & \\
\hline Ryu et al. [30] & $\mathrm{O} 4$ & 40 & 17 & 7 & 10 & 0 & & 17 & & Laparoscopic & $\mathrm{E}$ & $0-2 \mathrm{~h}$ : early period \\
\hline \multirow{2}{*}{ Study 2} & 08 & 40 & 8 & 3 & 4 & 0 & & 8 & & Cholecystectomy & & \\
\hline & $\mathrm{R} 0.3$ & 40 & 8 & 1 & 4 & 0 & & 8 & & & & \\
\hline Jeon et al. [34] & $\mathrm{R} 0.3$ & 60 & & & & & 8 & 4 & 26 & Thyroidectomy & After IND & \\
\hline \multirow{2}{*}{ Study 3} & D8 & 60 & & & & & 21 & 16 & 22 & & & \\
\hline & $\mathrm{R} 0.3+\mathrm{D} 8$ & 60 & & & & & 6 & 3 & 22 & & & \\
\hline Kim et al. [35] & $\mathrm{P}$ & 54 & 34 & 17 & 24 & 18 & 37 & 22 & 18 & Gynecological & E & $0-6 \mathrm{~h}$ : early period \\
\hline \multirow[t]{2}{*}{ Study 4} & 08 & 54 & 19 & 8 & 17 & 8 & 24 & 16 & 17 & Surgery & & \\
\hline & $\mathrm{R} 0.3$ & 54 & 18 & 4 & 22 & 7 & 27 & 8 & 20 & & & \\
\hline Lee et al. [36] & $\mathrm{P}$ & 40 & 13 & 6 & 12 & 10 & & 5 & 0 & Gynecological & Before & $0-1 \mathrm{~h}$ : early period \\
\hline \multirow[t]{2}{*}{ Study 5} & R0.1 (PO) & 40 & 4 & 4 & 6 & 7 & & 2 & 1 & Surgery & IND & Tin. cany perive \\
\hline & $\mathrm{R} 0.3$ & 40 & 4 & 3 & 5 & 2 & & 2 & 1 & & & \\
\hline Choi et al. [37] & $\mathrm{O} 4+12(\mathrm{PCA})+$ & 47 & 23 & 9 & 25 & 11 & & 18 & 27 & Spine surgery & E & $0-1 \mathrm{~h}$ : early period \\
\hline \multirow[t]{2}{*}{ Study 6} & R0.3 (24 h) & & & & & & & & & & & \\
\hline & $\mathrm{R} 0.3+0.3(24 \mathrm{~h})$ & 47 & 31 & 2 & 25 & 5 & & 16 & 14 & & & \\
\hline Lee et al. [38] & $\mathrm{P}$ & 77 & & & & & 57 & 41 & 12 & Breast surgery & $\mathrm{E}$ & \\
\hline \multirow[t]{2}{*}{ Study 7} & R0.1 & 79 & & & & & 22 & 12 & 20 & & & \\
\hline & R0.1 (PO) & 80 & & & & & 20 & 4 & 14 & & & \\
\hline Fujii et al. [24] & $\mathrm{P}$ & 20 & & & & & 10 & & & Termination of & E & \\
\hline Study 8 & R0.15 & 20 & & & & & 9 & & & Pregnancy & & \\
\hline & R0.3 & 20 & & & & & 3 & & & & & \\
\hline & R0.6 & 20 & & & & & 2 & & & & & \\
\hline Fujii et al. [31] & $\mathrm{P}$ & 30 & & & & & 14 & & 6 & Breast surgery & E & \\
\hline Study 9 & G3 & 30 & & & & & 5 & & 4 & & & \\
\hline & $\mathrm{R} 0.3$ & 30 & & & & & 3 & & 6 & & & \\
\hline Fujii et al. [39] & $\mathrm{P}$ & 20 & & & & & 15 & & & Total hip & E & \\
\hline Study 10 & R0.15 & 20 & & & & & 14 & & & Replacement & & \\
\hline & $\mathrm{R} 0.3$ & 20 & & & & & 5 & & & & & \\
\hline & R0.6 & 20 & & & & & 4 & & & & & \\
\hline Fujii et al. [23] & $\mathrm{P}$ & 25 & & & & & 15 & 6 & 4 & Middle ear surgery & Before IND & \\
\hline Study 11 & R0.15 & 25 & & & & & 13 & 5 & 5 & & & \\
\hline & R0.3 & 25 & & & & & 3 & 0 & 4 & & & \\
\hline & $\mathrm{R} 0.6$ & 25 & & & & & 2 & 0 & 4 & & & \\
\hline Fujii et al. [25] & $\mathrm{P}$ & 25 & & & & & 10 & & & Laparoscopic & E & \\
\hline Study 12 & R0.15 & 25 & & & & & 8 & & & Cholecystectomy & & \\
\hline & $\mathrm{R} 0.3$ & 25 & & & & & 2 & & & & & \\
\hline & R0.6 & 25 & & & & & 2 & & & & & \\
\hline Lee et al. [32] & $\mathrm{P}$ & 41 & & & & & 25 & 13 & 13 & Thyroidectomy & Before IND & \\
\hline Study 13 & $\mathrm{G} 20 \mu \mathrm{g} / \mathrm{kg}$ & 36 & & & & & 11 & 4 & 11 & & & \\
\hline & $\mathrm{R} 4 \mu \mathrm{g} / \mathrm{kg}$ & 36 & & & & & 18 & 7 & 15 & & & \\
\hline Fujii et al. [26] & $\mathrm{P}$ & 20 & & & & & 12 & & & Thyroidectomy & $\mathrm{E}$ & \\
\hline Study 14 & R0.15 & 20 & & & & & 10 & & & & & \\
\hline & $\mathrm{R} 0.3$ & 20 & & & & & 3 & & & & & \\
\hline & $\mathrm{R} 0.6$ & 20 & & & & & 2 & & & & & \\
\hline Fujii et al. [40] & G3 & 40 & & & & & 7 & & 6 & Thyroidectomy & E & \\
\hline Study 15 & $\mathrm{R} 0.3$ & 40 & & & & & 5 & & 5 & & & \\
\hline Fujii et al. [22] & $\mathrm{P}$ & 30 & 9 & 11 & 8 & 10 & & & & Gynecological & E & $0-3 \mathrm{~h}$ : early period \\
\hline Study 16 & R0.15 & 30 & 9 & 9 & 8 & 8 & & & & Surgery & & \\
\hline & $\mathrm{R} 0.3$ & 30 & 2 & 3 & 3 & 2 & & & & & & \\
\hline & R0.6 & 30 & 2 & 2 & 2 & 2 & & & & & & \\
\hline Fujii et al. [41] & G3 & 50 & & & & & 7 & & 7 & Middle ear surgery & Before IND & \\
\hline Study17 & $\mathrm{R} 0.3$ & 50 & & & & & 5 & & 6 & & & \\
\hline Fujii et al. [28] & G3 & 40 & & & & & 6 & & & Laparoscopic & E & \\
\hline Study 18 & $\mathrm{R} 0.3$ & 40 & & & & & 3 & & & Cholecystectomy & & \\
\hline Fujii et al. [33] & $\mathrm{G} 2.5$ & 60 & 5 & 5 & 5 & 6 & & & & Gynecological & E & $0-3 \mathrm{~h}$ : early period \\
\hline Study 19 & $\mathrm{R} 0.3$ & 60 & 3 & 3 & 3 & 4 & & & & Surgery & & \\
\hline Fujii et al. [5] & $\mathrm{P}$ & 20 & & & & & 15 & 6 & & Strabismus surgery & $\mathrm{E}$ & Children \\
\hline Study 20 & $\mathrm{R} 3 \mu \mathrm{g} / \mathrm{kg}$ & 20 & & & & & 13 & 5 & & & & Only retching and \\
\hline & $\mathrm{R} 6 \mu \mathrm{g} / \mathrm{kg}$ & 20 & & & & & 2 & 0 & & & & Vomiting \\
\hline & $\mathrm{R} 12 \mu \mathrm{g} / \mathrm{kg}$ & 20 & & & & & 2 & 0 & & & & \\
\hline Fujii et al. [20] & $\mathrm{P}$ & 20 & & & & & 14 & 6 & & Tonsillectomy & E & Children \\
\hline Study 21 & $\mathrm{R} 3 \mu \mathrm{g} / \mathrm{kg}$ & 20 & & & & & 13 & 5 & & & & Only retching and \\
\hline & $\mathrm{R} 6 \mu \mathrm{g} / \mathrm{kg}$ & 20 & & & & & 2 & 0 & & & & Vomiting \\
\hline & $\mathrm{R} 12 \mu \mathrm{g} / \mathrm{kg}$ & 20 & & & & & 2 & 0 & & & & \\
\hline Fujii et al. [21] & $\mathrm{G} 40 \mu \mathrm{g} / \mathrm{kg}$ & 40 & & & & & 6 & & & Strabismus surgery & E & Children \\
\hline Study 22 & $\mathrm{R} 6 \mu \mathrm{g} / \mathrm{kg}$ & 40 & & & & & 4 & & & & & $\begin{array}{l}\text { Only retching and } \\
\text { Vomiting }\end{array}$ \\
\hline
\end{tabular}

P: placebo,O4, 8: ondansetron 4, 8 mg, O12 (PCA): ondansetron $12 \mathrm{mg}$ through PCA, R0. 0.15, 0.3, 0.6: ramosetron 0.15, 0.3, 0.6 mg, R0.6 (PCA): ramosetron $0.6 \mathrm{mg}$ through PCA, R0.1: ramosetron $0.1 \mathrm{mg}$ per oral, R0.3 $(24 \mathrm{~h})$ : ramosetron injected at 24 hours after surgery, G2.5, 3: grainsetron 2.5, $3 \mathrm{mg}$, D8: dexamethasone $8 \mathrm{mg}$, R4 $\mu \mathrm{g} / \mathrm{kg}$ : ramosetron $0.24 \mathrm{mg}$ (assuming an average body weight of $60 \mathrm{~kg}$ ) and was included in R0.3, PON: postoperative nausea, POV: postoperative vomiting (including retching), PONV: postoperative nausea and vomiting, early period: $<6$ hours, late: 1-24 hours, AE: Adverse effects. E: IV at end of surgery, IND: induction. 


\section{$0.3 \mathrm{mg}$ ramosetron versus placebo}

All trials (studies 4, 5, 16) showed a benefit of $0.3 \mathrm{mg}$ ramosetron in the prevention of early PON (RR: $0.4 ; 95 \% \mathrm{CI}$, $0.3-0.7$ ), early POV (RR: $0.3 ; 95 \%$ CI $0.2-0.6$ ), and late POV (RR: 0.3; 95\% CI, 0.1-0.6), but not late PON (RR: 0.6; 95\% CI, 0.31.2). Ramosetron at this dose was compared with placebo in 9 trials of overall PONV, 5 trials of rescue-need, 5 trials of adverse effects in adults, and 2 trials of overall PONV and rescueneed in children (studies 20, 21, Table 1). All results in overall PONV and rescue-need showed a significant effect of $0.3 \mathrm{mg}$ ramosetron in adults and $6 \mu \mathrm{g} / \mathrm{kg}$ in children because the $95 \%$ CI did not include the value of 1.0 (Fig. 2). Comparing $0.3 \mathrm{mg}$ ramosetron and placebo, RR in adults was 0.5 (95\% CI, 0.3-0.6), and NNT was 3.3 in overall PONV. In rescue-needed trials, RR was 0.5 (95\% CI, $0.3-0.8)$, and NNT was 5 . In trials with adverse effects, RR was 1.2 (95\% CI, 0.8-1.6), and NNT was 33 without significant difference (Fig. 3). As no heterogeneity was found except in overall PONV when comparing $0.3 \mathrm{mg}$ ramosetron and placebo, a subgroup analysis of different time points of ramosetron administration was performed. However, different time points did not affect heterogeneity.

\section{$0.3 \mathrm{mg}$ ramosetron versus $3 \mathrm{mg}$ granisetron}

$0.3 \mathrm{mg}$ ramosetron was compared with $3 \mathrm{mg}$ granisetron in 4 trials of overall PONV and 3 trials of adverse effects in adults (Table 1). RR was 0.6 (95\% CI, $0.3-1.2)$ in overall PONV and 1 (95\% CI, 0.5-1.8) in adverse effects. Therefore, no significant difference was found between $0.3 \mathrm{mg}$ ramosetron and $3 \mathrm{mg}$ granisetron.

\begin{tabular}{|c|c|c|c|}
\hline Study ID & Year & $\begin{array}{l}\text { Exposed } \\
n[e](E=1) / n[e]\end{array}$ & $\begin{array}{l}\text { Control } \\
n[c](E=1) / n[c]\end{array}$ \\
\hline Study \# 1 & & $38 / 70$ & $49 / 70$ \\
\hline Study \# 4 & & $27 / 54$ & $37 / 54$ \\
\hline Study \# 8 & & $3 / 20$ & $10 / 20$ \\
\hline Study \# 9 & & $3 / 30$ & $14 / 30$ \\
\hline Study \# 10 & & $5 / 20$ & $15 / 20$ \\
\hline Study \# 11 & & $3 / 25$ & $15 / 25$ \\
\hline Study \# 12 & & $2 / 25$ & $10 / 25$ \\
\hline Study \# 13 & & $18 / 36$ & $25 / 41$ \\
\hline Study \# 14 & & $3 / 20$ & $12 / 20$ \\
\hline Study \# 20 & & $2 / 20$ & $15 / 20$ \\
\hline Study \# 21 & & $2 / 20$ & $14 / 20$ \\
\hline Meta-analysis: & & $106 / 340$ & $216 / 345$ \\
\hline
\end{tabular}
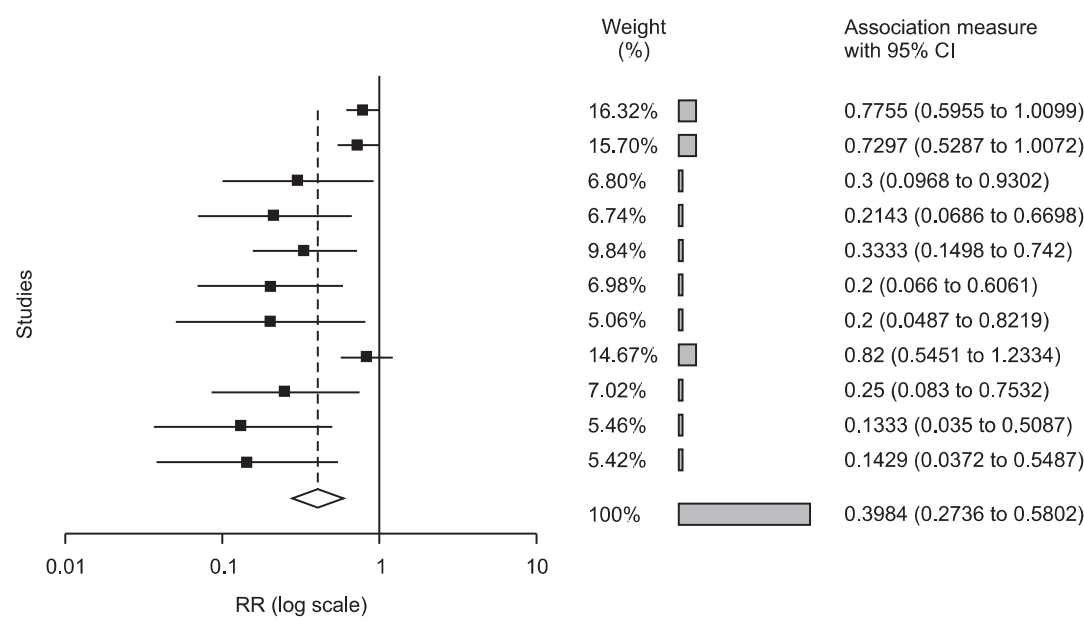

Fig. 2. Annotated forest plot (overall PONV: $0.3 \mathrm{mg}$ ramosetron in adults and $6 \mu \mathrm{g} / \mathrm{kg}$ in children, studies 20, 21) depicted individual trials as filled squares with relative size of weights and horizontal bars as the confidence interval. The bottom diamond shape indicates the pooled value.

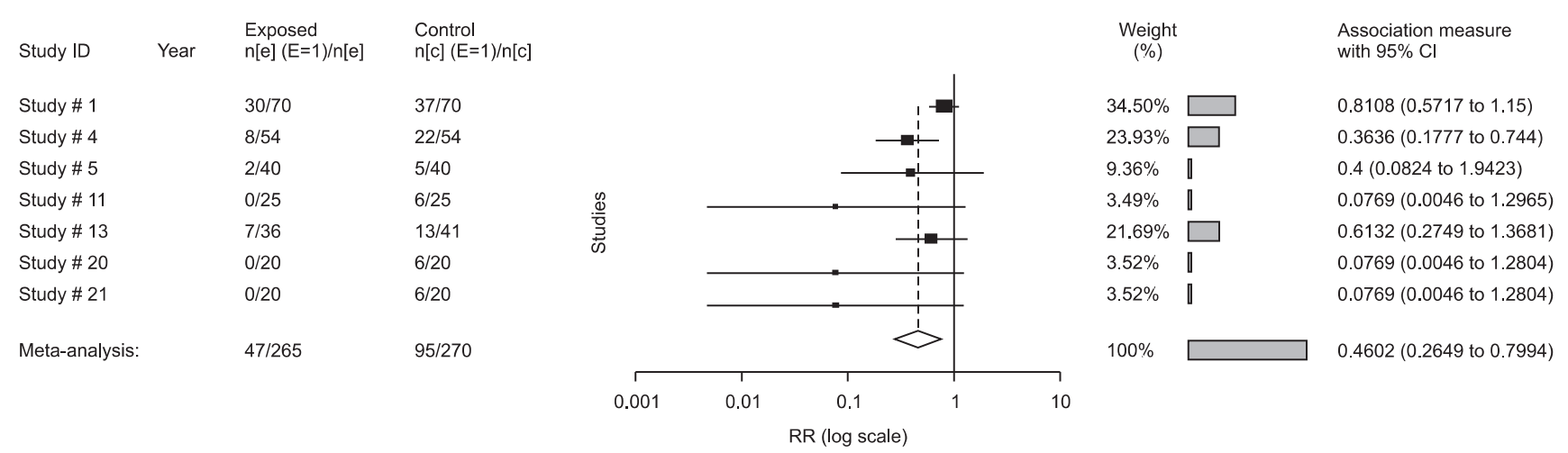

Fig. 3. Annotated forest plot (rescue-need: $0.3 \mathrm{mg}$ ramosetron in adults and $6 \mu \mathrm{g} / \mathrm{kg}$ in children (studies 20, 21) depicted individual trials as filled squares with relative size of weights and horizontal bars as the confidence interval. The bottom diamond shape indicates the pooled value. 


\section{Ramosetron versus other antiemetics or combination therapy}

As several trials compared ramosetron with other active drugs, combined data analysis was performed with respect to the route of administration (e.g. per oral and PCA), different time points of application (e.g. before and after induction), and different doses of active drugs (e.g. ondansetron and dexamethasone). Due to insufficient or missing appropriate data to combine or compare, no further analysis was conducted (Table 1).

\section{Adverse effects}

Several trials reported adverse effects, including headache, dizziness, constipation/diarrhea, muscle pain, and drowsiness/ sedation. No weighting was used for different grades of adverse effects. Headache was the most often observed adverse effect, but all adverse events were transient and clinically insignificant. There were no severe adverse events, and no trials presented any statistically significant difference between ramosetron and placebo or granisetron.

\section{Discussion}

Despite extensive research and the introduction of ramosetron with better efficacy and safety profiles, there seems to be very few articles which assessed the drug using valid methods. In 18 RCTs, we observed a small number of patients suffering from PONV following administration of a fixed dose of $0.3 \mathrm{mg}$ ramosetron in adults and $6 \mu \mathrm{g} / \mathrm{kg}$ in children without any serious adverse effects. Such results indicate that ramosetron is an effective and well-accepted prophylactic antiemetic in early, late, and overall periods. Antiemetic effect in early and late POV and late POV were similar. In spite of significant differences between overall PONV and rescue-need, late PON did not show difference from placebo, which remains to be clarified. Ramosetron has a long half-life $(5.8 \mathrm{~h})$, and its antiemetic effect when given as an IV bolus lasted up to $48 \mathrm{~h}[22,27,28]$. Several reports concluded $0.3 \mathrm{mg}$ ramosetron is the minimum effective dose, and no more than $0.3 \mathrm{mg}$ was needed in adults and $6 \mu \mathrm{g} /$ $\mathrm{kg}$ in children [5,20-26]. Addition of ondansetron to PCA or 8 mg IV ondansetron was as effective as $0.3 \mathrm{mg}$ ramosetron, and the same efficacy was observed with granisetron [28-33]. We need more data for combination therapy, as there is no report on any additive or synergic antiemetic effects of the combination of ramosetron with other active drugs. An optimal dose of combination therapy needs to be identified.

Although this meta-analysis suggested that a dose of $0.3 \mathrm{mg}$ ramosetron in adults and $6 \mu \mathrm{g} / \mathrm{kg}$ in children is effective and safe for the prevention of PONV, there are some issues to be addressed. Heterogeneity of combing results $\left(\mathrm{I}^{2}\right.$-test: $\left.74 \%\right)$ from all relevant reports was revealed in overall PONV. Multi-factorial sources might be attributed to different types of surgery, anesthetic techniques, sex, age, and route and timing of drug administration. Subgroup analysis did not clearly exclude an underlying subtle risk factor to classify an interaction because of a different preoperative PONV risk profile of each trial. A significantly better antiemetic efficacy and safety of ramosetron in comparison with placebo was revealed in data analysis by age, timing of drug administration, and surgery type.

Although responses to different prophylactic doses were not investigated due to insufficient data, a fixed dose of 0.3 $\mathrm{mg}$ ramosetron in adults and $6 \mu \mathrm{g} / \mathrm{kg}$ in children seemed to be a rational option in practice in overall period. NNT 3.3 of overall PONV indicated that patients at risk of nausea and vomiting were likely to benefit by intervention of $0.3 \mathrm{mg}$ ramosetron in adults and $6 \mu \mathrm{g} / \mathrm{kg}$ in children. This means that 1 in 3 patients who are suffering from nausea or vomiting and would otherwise continue to suffer with placebo will be prevented from further nausea and vomiting with ramosetron treatment. However, because of the small number of studies and participating subjects in early and late periods, this review could not give clear and real suggestions regarding the effect of the drug in each period. An insufficient number of reports on trials in children, combination therapy, and comparison with other active drugs could have potentially provided misleading information and thus require larger observational studies.

The most frequently reported adverse effect was headache, and others were limited to dizziness, constipation/diarrhea, muscle pain, and drowsiness/sedation. There was no significant difference in adverse events between ramosetron and placebo or granisetron. The severity of the adverse effects was considered to be mild to moderate, and was resolved with no intervention. Ramosetron was judged as safe in this review.

This study has some limitations. First, there may be a publication bias although we tried to minimize it in the process of article selection. Publication bias shown by a funnel plot (Fig. 4) may alter the results of this review. In general, a positive result of trials may usually be easier to report than a negative one. Causes of other than publication bias should be made caution for any interpretation in funnel plot. Second, our result in overall PONV revealed heterogeneity despite the inclusion of 18 RCTs with 1888 patients, which limits drawing a general conclusion and providing any recommendation. Accordingly, a limited comparison was performed for a fixed dose of $0.3 \mathrm{mg}$ ramosetron in adults and $6 \mu \mathrm{g} / \mathrm{kg}$ in children where possible. Third, there were a small number of trials on combination therapy and children, which limited the pooled analysis.

This review demonstrated that intervention with $0.3 \mathrm{mg}$ 


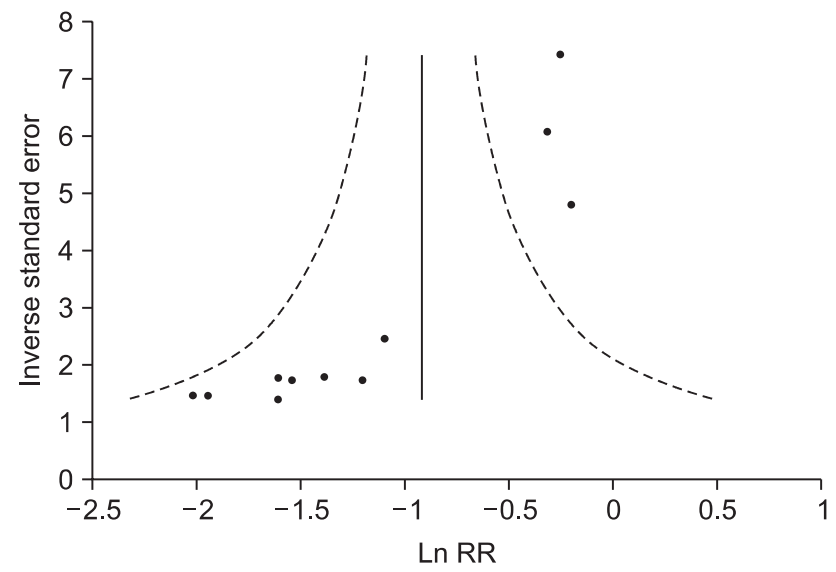

Fig. 4. Funnel plot showing a potential publication bias through asymmetry (overall PONV: $0.3 \mathrm{mg}$ ramosetron in adults and $6 \mu \mathrm{g}$ / $\mathrm{kg}$ in children (studies 20,21) depicted individual trials as filled squares. Ln RR: log relative risk.

ramosetron in adults and $6 \mu \mathrm{g} / \mathrm{kg}$ in children was highly efficacious and safe in surgical setting when applied before induction or at the end of surgery. Indeed, our result indicated that ramosetron provided potential clinical advantages with minimal adverse effects and reduced overall PONV after anesthesia in both adult and pediatric patients. The drug is a good alternative over existing drugs and prophylactics of PONV. However, available data were sparse and limited, and further trials are warranted to assess its effect on children, timing and route of application, comparisons with other active drugs, or combination therapy. Well-designed larger trials are needed to elucidate the relationship between ramosetron and a preoperative risk profile.

\section{References}

1. Fujii Y. Management of postoperative nausea and vomiting in patients undergoing laparoscopic cholecystectomy. Surg Endosc 2011; 25: 691-5.

2. Fujii Y. Prevention of nausea and vomiting during termination of pregnancy. Int J Gynaecol Obstet 2010; 111: 3-7.

3. Rose JB, Watcha MF. Postoperative nausea and vomiting in paediatric patients. Br J Anaesth 1999; 83: 104-17.

4. Bolton CM, Myles PS, Nolan T, Sterne JA. Prophylaxis of postoperative vomiting in children undergoing tonsillectomy: a systematic review and meta-analysis. Br J Anaesth 2006; 97: 593-604.

5. Fujii $Y$, Tanaka H, Ito M. A randomized clinical trial of a single dose of ramosetron for the prevention of vomiting after strabismus surgery in children: a dose-ranging study. Arch Ophthalmol 2005; 123: 25-8.

6. Ku CM, Ong BC. Postoperative nausea and vomiting: a review of current literature. Singapore Med J 2003; 44: 366-74.

7. Henzi I, Walder B, Tramer MR. Dexamethasone for the prevention of postoperative nausea and vomiting: a quantitative systematic review. Anesth Analg 2000; 90: 186-94.

8. Hahm TS, Ko JS, Choi SJ, Gwak MS. Comparison of the prophylactic anti-emetic efficacy of ramosetron and ondansetron in patients at high-risk for postoperative nausea and vomiting after total knee replacement. Anaesthesia 2010; 65: 500-4.

9. Lee HK, Lee JH, Chon SS, Ahn EK, Kim JH, Jang YH. The effect of transdermal scopolamine plus intravenous dexamethasone for the prevention of postoperative nausea and vomiting in patients with epidural PCA after major orthopedic surgery. Korean J Anesthesiol 2010; 58: 50-5.

10. Fujii Y. Current management of vomiting after tonsillectomy in children. Curr Drug Saf 2009; 4: 62-73.

11. Rabasseda X. Ramosetron, a 5-HT3 receptor antagonist for the control of nausea and vomiting. Drugs Today (Barc) 2002; 38: 75-89.

12. Hesketh PJ, Gandara DR. Serotonin antagonists: a new class of antiemetic agents. J Natl Cancer Inst 1991; 83: 613-20.

13. Liberati A, Altman DG, Tetzlaff J, Mulrow C, Gotzsche PC, Ioannidis JP, et al. The PRISMA statement for reporting systematic reviews and meta-analyses of studies that evaluate health care interventions: explanation and elaboration. J Clin Epidemiol 2009; 62: e1-34.

14. Moher D, Liberati A, Tetzlaff J, Altman DG; PRISMA Group. Reprint-preferred reporting items for systematic reviews and metaanalyses: the PRISMA statement. Phys Ther 2009; 89: 873-80.

15. Watcha MF, White PF. Postoperative nausea and vomiting. Its etiology, treatment, and prevention. Anesthesiology 1992; 77: 16284.

16. Gan TJ, Meyer TA, Apfel CC, Chung F, Davis PJ, Habib AS, et al. Society for Ambulatory Anesthesia guidelines for the management of postoperative nausea and vomiting. Anesth Analg 2007; 105: 1615-28.

17. Jadad AR, Moore RA, Carroll D, Jenkinson C, Reynolds DJ, Gavaghan DJ, et al. Assessing the quality of reports of randomized clinical trials: is blinding necessary? Control Clin Trials 1996; 17: 1-12.

18. Bax L, Yu LM, Ikeda N, Tsuruta H, Moons KG. Development and validation of MIX: comprehensive free software for meta-analysis of causal research data. BMC Med Res Methodol 2006; 6: 50.

19. Bax L, Yu LM, Ikeda N, Moons KG. A systematic comparison of software dedicated to meta-analysis of causal studies. BMC Med Res Methodol 2007; 7: 40.

20. Fujii Y, Tanaka H. Results of a prospective, randomized, doubleblind, placebo-controlled, dose-ranging trial to determine the effective dose of ramosetron for the prevention of vomiting after tonsillectomy in children. Clin Ther 2003; 25: 3135-42.

21. Fujii Y, Tanaka H, Ito M. Ramosetron compared with granisetron for the prevention of vomiting following strabismus surgery in children. Br J Ophthalmol 2001; 85: 670-2.

22. Fujii Y, Saitoh Y, Tanaka H, Toyooka H. Ramosetron for preventing postoperative nausea and vomiting in women undergoing gynecological surgery. Anesth Analg 2000; 90: 472-5.

23. Fujii Y, Tanaka H. Randomized, double-blind, placebo-controlled, dosed-finding study of the antiemetic effects and tolerability of ramosetron in adults undergoing middle ear surgery. Clin Ther 2003; 25: 3100-8.

24. Fujii Y, Tanaka H, Somekawa Y. A randomized, double-blind, placebocontrolled trial of ramosetron for preventing nausea and vomiting during termination of pregnancy. Int J Obstet Anesth 2004; 13: 15-8. 
25. Fujii Y, Uemura A, Tanaka H. Prophylaxis of nausea and vomiting after laparoscopic cholecystectomy with ramosetron: randomised controlled trial. Eur J Surg 2002; 168: 583-6.

26. Fujii Y, Tanaka H. Double-blind, placebo-controlled, dose-ranging study of ramosetron for the prevention of nausea and vomiting after thyroidectomy. Clin Ther 2002; 24: 1148-53.

27. Roila F, Del Favero A. Ondansetron clinical pharmacokinetics. Clin Pharmacokinet 1995; 29: 95-109.

28. Fujii Y, Saitoh Y, Tanaka H, Toyooka H. Ramosetron vs granisetron for the prevention of postoperative nausea and vomiting after laparoscopic cholecystectomy. Can J Anaesth 1999; 46: 991-3.

29. Choi DK, Chin JH, Lee EH, Lim OB, Chung CH, Ro YJ, et al. Prophylactic control of post-operative nausea and vomiting using ondansetron and ramosetron after cardiac surgery. Acta Anaesthesiol Scand 2010; 54: 962-9.

30. Ryu J, So YM, Hwang J, Do SH. Ramosetron versus ondansetron for the prevention of postoperative nausea and vomiting after laparoscopic cholecystectomy. Surg Endosc 2010; 24: 812-7.

31. Fujii Y, Tanaka H, Kawasaki T. Benefits and risks of granisetron versus ramosetron for nausea and vomiting after breast surgery: a randomized, double-blinded, placebo-controlled trial. Am J Ther 2004; 11:278-82.

32. Lee SY, Lee JY, Park SY, Kim JH, Cho OG, Kim JS, et al. Prophylactic antiemetic efficacy of granisetron or ramosetron in patients undergoing thyroidectomy. Asian J Surg 2002; 25: 309-14.

33. Fujii Y, Saitoh Y, Tanaka H, Toyooka H. Comparison of ramosetron and granisetron for preventing postoperative nausea and vomiting after gynecologic surgery. Anesth Analg 1999; 89: 476-9.

34. Jeon Y, Kim H, Kwak K. Comparison of ramosetron, dexamethasone, and a combination of ramosetron and dexamethasone for the prevention of postoperative nausea and vomiting in Korean women undergoing thyroidectomy: A double-blind, randomized, controlled study. Current Therapeutic Research 2010; 71: 78-88.

35. Kim SI, Kim SC, Baek YH, Ok SY, Kim SH. Comparison of ramosetron with ondansetron for prevention of postoperative nausea and vomiting in patients undergoing gynaecological surgery. Br J Anaesth 2009; 103: 549-53.

36. Lee D, Kim JY, Shin JW, Ku CH, Park YS, Kwak HJ. The effect of oral and IV ramosetron on postoperative nausea and vomiting in patients undergoing gynecological laparoscopy with total intravenous anesthesia. J Anesth 2009; 23: 46-50.

37. Choi YS, Shim JK, Yoon do H, Jeon DH, Lee JY, Kwak YL. Effect of ramosetron on patient-controlled analgesia related nausea and vomiting after spine surgery in highly susceptible patients: comparison with ondansetron. Spine (Phila Pa 1976) 2008; 33: E602-6.

38. Lee HJ, Kwon JY, Shin SW, Kim CH, Baek SH, Baik SW, et al. Preoperatively administered ramosetron oral disintegrating tablets for preventing nausea and vomiting associated with patient-controlled analgesia in breast cancer patients. Eur J Anaesthesiol 2008; 25: 756 62.

39. Fujii Y, Tanaka H. Prevention of nausea and vomiting with ramosetron after total hip replacement. Clin Drug Investig 2003; 23: 405-9.

40. Fujii Y, Tanaka H. Comparison of granisetron and ramosetron for the prevention of nausea and vomiting after thyroidectomy. Clin Ther 2002; 24: 766-72.

41. Fujii Y, Tanaka H, Kobayashi N. Prevention of nausea and vomiting after middle ear surgery: granisetron versus ramosetron. Laryngoscope 1999; 109: 1988-90. 